\title{
Novel virulence, antibiotic resistance and toxin gene-specific PCR-based assays for rapid pathogenicity assessment of Arcobacter faecis and Arcobacter lanthieri
}

Matthew Zambri, ${ }^{1,2}$, Michel Cloutier', Zaky Adam¹,3, David R. Lapen', Graham Wilkes ${ }^{1}$, Mark Sunohara', Edward Topp ${ }^{4}$, Guylaine Talbot ${ }^{5}$ and Izhar U. H. Khan ${ }^{1 *}$ (D)

\begin{abstract}
Background: Arcobacter faecis and A. lanthieri are two newly classified species of genus Arcobacter. The prevalence and distribution of virulence, antibiotic resistance and toxin (VAT) genes in these species are required to assess their potential pathogenic health impacts to humans and animals. This study (i) developed species- and gene-specific primer pairs for the detection of six virulence, two antibiotic resistance, and three toxin genes in two target species; (ii) optimized eight single-tube multiplex and three monoplex PCR protocols using the newly developed speciesand gene-specific primers; and (iii) conducted specificity and sensitivity evaluations as well as validation of eleven mono- and multiplex PCR assays by testing A. faecis $(n=29)$ and A. lanthieri $(n=10)$ strains isolated from various fecal and agricultural water sources to determine the prevalence and distribution of VAT genes and assess the degree of pathogenicity within the two species.

Results: Detection of all ten and eleven target VAT genes, and expression of cytolethal distending toxin (cdtA, $c d t B$ and $c d t C$ ) genes in $A$. faecis and $A$. lanthieri reference strains with high frequency in field isolates suggest that they are potentially pathogenic strains. These findings indicate that these two species can pose a health risk to humans and animals.

Conclusions: The study results show that the developed mono- and multiplex PCR (mPCR) assays are simple, rapid, reliable and sensitive for the simultaneous assessment of the potential pathogenicity and antibiotic resistance profiling of tet $(\mathrm{O})$ and tet $(\mathrm{W})$ genes in these two newly discovered species. Also, these assays can be useful in diagnostic and analytical laboratories to determine the pathotypes and assessment of the virulence and toxin factors associated to human and animal infections.
\end{abstract}

Keywords: Mono- and multiplex PCR, Arcobacter faecis, A. lanthieri, Pathogenicity, Virulence, Antibiotic resistance, Toxins

\footnotetext{
*Correspondence: izhar.khan@canada.ca

'Ottawa Research and Development Centre (ORDC), Agriculture and

Agri-Food Canada, 960 Carling Ave., Ottawa, Ontario K1A 0C6, Canada

Full list of author information is available at the end of the article
}

C Crown. 2019 Open Access This article is distributed under the terms of the Creative Commons Attribution 4.0 International License (http://creativecommons.org/licenses/by/4.0/), which permits unrestricted use, distribution, and reproduction in any medium, provided you give appropriate credit to the original author(s) and the source, provide a link to the Creative Commons license, and indicate if changes were made. The Creative Commons Public Domain Dedication waiver (http:// creativecommons.org/publicdomain/zero/1.0/) applies to the data made available in this article, unless otherwise stated. 


\section{Highlights}

1. Species- and gene-specific mPCR assays were developed, optimized and validated for $A$. faecis and $A$. lanthieri

2. Virulence, antibiotic resistance and toxin genes were rapidly detected in field isolates

3. Evaluation of Pathogenicity of A. faecis and A. lanthieri strains

\section{Introduction}

The genus Arcobacter was proposed in 1991 by Vandamme et al. [1], separating it from genus Campylobacter. It was further amended and enlarged to include a total of over 27 species, with the reclassification of other Arcobacter spp. isolated from various human, animal and environmental sources [2-4]. The Arcobacter spp., particularly A. butzleri, A. cryaerophilus, A. skirrowii, and A. cibarius, are of interest to research groups because of their prevalence in bovine, porcine, poultry and shellfish $[5,6]$. These species have been considered as emerging food- and waterborne zoonotic pathogens [7]. Arcobacter spp. have been associated with various illnesses such as gastroenteritis, bacteremia, and sepsis in humans, mastitis, diarrhea, abortion, and other reproductive disorders in animals [8]. Infection caused by the genus Arcobacter spp. is still considered as a low public health risk because of misidentification by inappropriate detection and typing methods of both Campylobacter and Arcobacter spp., which result in underestimation of the true incidence of Arcobacter infection [9]. Moreover, there is a limited knowledge of key mechanisms (e.g., adhesion, invasion, and cytotoxicity capacity) and potential virulence and toxin factors of Arcobacter spp. [6, 10, 11]. The pathogenesis of bacterial infection depends on enterotoxins, adherence and colonization factors as well as invasiveness and penetrability characteristics where pathogens causing gastrointestinal infection either attach to the surface of epithelial cells or invade the intestinal epithelial cells and replicate in the intestinal lumen and produce a systemic disease [12].

Among several Arcobacter spp., A. faecis and A. lanthieri are two recently discovered species within the genus Arcobacter which were recovered from human waste septic tank and livestock manure, respectively $[4,13]$. The two species were distinguished with other Arcobacter spp. through polyphasic approaches that examined several genotypic and phenotypic aspects of $A$. faecis (LMG $28516^{\mathrm{T}}$ ) and A. lanthieri (LMG $28519^{\mathrm{T}}$ ) reference strains $[4,13]$. Through the genetic analysis performed on the multiple housekeeping gene sequences, it was reported that the two novel species were most closely related to each other as well as to the
A. cibarius, A. butzleri, A. cryaerophilus and A. skirrowii. Since these two Arcobacter spp. have been isolated from human and animal fecal sources, it is important to investigate the degree of pathogenicity of these species that can aid in identifying their potential relevance to human and animal infections.

Studies have previously evaluated the occurrence and potential role of virulence-associated genes (VAGs) in the pathogenesis of human and animal infections by the Arcobacter spp. [10, 14]. Other studies have indicated that several VAGs are prevalent in the genus Arcobacter [14-16] which suggests that several of the Arcobacter spp. potentially possess the ability to pose a significant risk to human health. Among six virulence genes, cadF gene encodes for an integral membrane protein that serves as an adhesion factor which allows the bacteria to bind to the fibronectin proteins found in the extracellular matrix of the host's intestinal epithelial cells, and is also responsible for activating GTPases of bacterial cells, thus inducing their internalization [17]. The ciaB gene encodes for the Campylobacter invasion antigen B [18], whereas irgA gene encodes for an iron-regulated outer membrane protein. However, $m v i \mathrm{~N}$ gene encodes for an essential protein that is involved in peptidoglycan and cellular membrane synthesis and pldA gene encodes the outer membrane phospholipase A. In addition, tylA encodes for the exotoxin hemolysin A [19].

On the other hand, cytolethal distending toxin $(c d t)$ found in Gram-negative bacteria that has been shown to stall growth of eukaryotic cells in either the G0/G1 or G2/M phases of the cell cycle which inevitably results in cell death. The $c d t$ toxin functions as a heterotrimer of proteins encoded by three separate genes $(c d t \mathrm{~A}, c d t \mathrm{~B}$, and $c d t \mathrm{C}$ ) that have been recognized for the expression of cytotoxin production [20, 21]. Previous studies have reported the distinct absence of $c d t$ genes from Arcobacter spp. isolated from various sources as well as a genome sequence of $A$. butzleri strain [19, 22]. Interestingly, it has been determined that the $A$. faecis reference strain contained only sequences for the $c d t \mathrm{~A}$ and $c d t \mathrm{C}$ genes, compared to the A. lanthieri that revealed sequences for $c d t \mathrm{~A}, c d t \mathrm{~B}$ and $c d t \mathrm{C}$ genes, respectively $[23,24]$.

In addition to the pathogenicity aspect, antimicrobial resistance is a serious and increasing threat to human health since their use for growth promotion or treatment of livestock, poultry and aquaculture has a direct impact on this problem. Among several antimicrobial agents, tetracyclines are still considered a clinically relevant antibiotic with limited use due to dissemination of tolerance and resistance determinants [25]. However, tetracyclines are frequently used in livestock, poultry and aquaculture as therapeutic, prophylactic or growth promotors worldwide with significantly high usage in countries such as China and India compared to United 
States and Europe due to the ban of tetracycline and other antibiotics as growth promoters which enhances the emergence of antibiotic resistant strains, allergic reactions in humans and animals, and changes in environmental microflora and bacterial populations among other detrimental effects [26-30]. Studies have reported high resistance of $A$. cryaerophilus to tetracycline [31] compared to A. butzleri that has shown high susceptibility to tetracycline and strong and widespread resistance to several other antibiotics [32-34]. Tetracycline acts to prevent the synthesis of bacterial proteins by binding to the prokaryotic $30 \mathrm{~S}$ ribosomal subunit, thus inhibiting initiation of translation [35, 36]. This resistance is due to different tetracycline resistance (tet) genes [37]. Of more than 40 genes encoding tetracycline resistance (tet-genes) that have been characterized, $\operatorname{tet}(\mathrm{O})$ and $\operatorname{tet}(\mathrm{W})$ genes confer ribosomal protection from the inhibiting effect of tetracycline [36, 38]. Therefore, tet $(\mathrm{O})$ and tet $(\mathrm{W})$ genes were specifically selected for this study as they appear to be promiscuous in environmental organisms through different transfer mechanisms [39, 40], which makes them suitable candidates for understanding the degree of prevalence, distribution and further monitoring of other antibiotic resistance genes in these two species. In order to understand and identify whether these isolates are potentially pathogenic, several virulence, antibiotic and toxin (VAT) genes were identified in both A. faecis and A. lanthieri reference strains [23, $24]$ by whole-genome sequence analysis.

The present study was undertaken to determine the prevalence of these genes within the fecal matter and agricultural environment based on development and optimization of a total of eleven (three monoplex and eight multiplex) PCR assays using six virulence $(\operatorname{cadF}$, $c i a \mathrm{~B}, \operatorname{irg} \mathrm{A}, m v i \mathrm{~N}, p l d \mathrm{~A}$ and $t y l \mathrm{~A})$, three cytolethal distending toxin $(c d t \mathrm{~A}, c d t \mathrm{~B}$ and $c d t \mathrm{C})$ and two tetracycline $[\operatorname{tet}(\mathrm{O})$ and $\operatorname{tet}(\mathrm{W})]$ genes. The assays were further validated to evaluate the degree of pathogenicity using reference strains and culture isolates recovered from various fecal sources and agricultural surface water samples.

\section{Materials and methods}

\section{Reference strains and Arcobacter field culture isolation}

For this study, a total of 17 different Arcobacter spp. along with 25 other bacterial reference species and strains isolated from various sources were used to test the newly developed assays (Table 1). The reference strains were grown on selective culture media under specific culture conditions.

In addition, 29 A. faecis and ten A. lanthieri culture strains isolated from various environment including agricultural surface water and fecal sources were tested for assessment, validation and application of the three monoplex and eight multiplex PCR assays. Arcobacter cultures were recovered from human and animal fecal and agricultural water sources using a method previously described by Whiteduck-Léveillée et al. [13]. Briefly, the fecal samples were collected under aseptic conditions using sterile spatula and containers, and $1 \mathrm{~g}$ of fecal sample was ten-fold serially diluted by mixing in $9 \mathrm{~mL}$ of peptone water. The suspension $(100 \mu \mathrm{L})$ was directly plated on Arcobacter Selective Isolation Agar (ASIA) (Oxoid, Nepean, ON) containing antimicrobial (fluorouracil, amphotericin- $\mathrm{B}$, cefoperazone, novobiocin and trimethoprim) agents. However, the recovery of Arcobacter cultures from agricultural surface water samples, collected in sterile polypropylene bottles, was carried out by processing $500 \mathrm{~mL}$ of water through $0.22 \mu \mathrm{m}$ sterile nitrocellulose filter using a vacuum-filtration system. The filters were placed on ASIA plate and incubated at $30^{\circ} \mathrm{C}$ under microaerophilic condition $(85 \%$ $\mathrm{N}_{2}, 10 \% \mathrm{CO}_{2}$ and $5 \% \mathrm{O}_{2}$ ) for 3 to 6 days. The presumptive Arcobacter culture isolates were, initially, selected based on conventional cultural characteristics (growth pattern and colony morphology) and Gram staining reactions. Further confirmation was carried out by Arcobacter genus- and species- specific PCR assays [41, 42].

\section{Tetracycline susceptibility test}

For pheno- and genotypic analysis, susceptibility of $A$. faecis and A. lanthieri strains to tetracycline was tested on Mueller-Hinton agar (Oxoid) using the agar dilution method according to CLSI [43]. The plates were incubated for 3 days in a microaerophilic condition at $30^{\circ} \mathrm{C}$. Results were interpreted in accordance with the CSLI guidelines [44].

\section{Nucleic acid extraction}

For assay development, optimization and validation, the nucleic acid was extracted from reference strains and Arcobacter culture isolates recovered from surface water and fecal samples according to previously described boiling method [45]. Briefly, a single purified colony was suspended and gently mixed in a $100 \mu \mathrm{L}$ 1 xTE (pH 8.0) buffer. The cells were boiled (10 min.) and centrifuged $(1 \mathrm{~min}$.) at high speed. The purity and concentration of extracted DNA was determined by NanoDrop (ND-1000) spectrophotometer and agarose gel electrophoresis.

\section{Gene-specific primers design, development and optimization of mono- and multiplex PCR assays for $A$. faecis}

Based on a comprehensive whole-genome sequence analysis of $A$. faecis LMG 28519 reference strain, six virulence $(c a d \mathrm{~F}, \operatorname{cia} \mathrm{B} \operatorname{irg} \mathrm{A}, m v i \mathrm{~N}, p l d \mathrm{~A}$ and $t y l \mathrm{~A})$, two antibiotic resistance $[\operatorname{tet}(\mathrm{O})$ and $\operatorname{tet}(\mathrm{W})]$ and two cytolethal distending toxin ( $c d t \mathrm{~A}$ and $c d t \mathrm{C})$ genes were 
Table 1 List of reference strains of Arcobacter and other bacterial species used in this study

\begin{tabular}{|c|c|c|c|}
\hline Sr. \# & Species & Source & Strain ID \\
\hline 1 & Arcobacter bivalviorum & Shellfish & LMG 26154 \\
\hline 2 & A. butzleri & Human diarrheic stool & ATCC 49616 \\
\hline 3 & A. cibarius & Broiler carcasses & LMG 21996 \\
\hline 4 & A. cryaerophilus & Bovine aborted fetus & NCTC 11885 \\
\hline 5 & A. defluvii & Sewage & LMG25694 \\
\hline 6 & A. ellisii & Mussels & LMG 26115 \\
\hline 7 & A. faecis & Human septic tank & LMG 28519 \\
\hline 8 & A. halophilus & Hypersaline lagoon & ATCC BAA-1022 \\
\hline 9 & A. lanthieri & Pig manure & LMG 28516 \\
\hline 10 & A. marinus & Mix seawater, starfish and seaweed & LMG 25770 \\
\hline 11 & A. molluscorum & Mussels and oysters & LMG 25693 \\
\hline 12 & A. mytili & Mussels & LMG 24559 \\
\hline 13 & A. nitrofigilis & Roots & ATCC 33309 \\
\hline 14 & A. skirrowii & Lamb feces & ATCC 51322 \\
\hline 15 & A. thereius & Organs of aborted porcine & LMG 24486 \\
\hline 16 & A. trophiarum & Feces of fattening pigs & LMG 25534 \\
\hline 17 & A. venerupis & Shellfish & LMG 26156 \\
\hline 18 & Aeromonas allosaccharophila & Diseased elvers & ATCC 51208 \\
\hline 19 & A. bestiarum & Infected fish & ATCC 51108 \\
\hline 20 & A. caviae & Epizootic of young guinea pigs & ATCC 15468 \\
\hline 21 & A. hydrophila & Ditch water & ATCC 13444 \\
\hline 22 & A. jandaei & Human feces & ATCC 49568 \\
\hline 23 & A. media & Marine fish & CDC 0435-84 \\
\hline 24 & A. popoffi & Drinking water production plant & BAA-243 \\
\hline 25 & A. salmonicida & Freshwater & CDC 0434-84 \\
\hline 26 & A. schubertii & Skin & ATCC 43700 \\
\hline 27 & A. sobria & Sludge & ATCC 35994 \\
\hline 28 & A. trota & Human feces & ATCC 49658 \\
\hline 29 & A. veronii & Red-leg frog & ATCC 9071 \\
\hline 30 & A. bv. veronii & Amputation Wound & ATCC 35625 \\
\hline 31 & Campylobacter jejuni & Human feces & ATCC 33291 \\
\hline 32 & C. coli & Swine & ATCC 43136 \\
\hline 33 & C. lari & Human feces & ATCC 43675 \\
\hline 34 & C. helveticus & Cat & ATCC 51210 \\
\hline 35 & C. fetus subsp. fetus & Blood & ATCC 15296 \\
\hline 36 & C. hyointestinalis & Intestine of swine & ATCC 35217 \\
\hline 37 & Escherichia coli O157:H7 & Environmental isolate & - \\
\hline 38 & E. coli & Canine & ATCC 35218 \\
\hline 39 & Pseudomonas shigelloides & Environmental isolate & - \\
\hline 40 & Salmonella enterica subsp. arizonae & - & ATC C 13314 \\
\hline 41 & S. enterica subps. diarizonae & - & ATCC 12325 \\
\hline 42 & S. enterica subsp. houtenae & - & ATCC 29932 \\
\hline
\end{tabular}


identified. After alignments of these VAT gene sequences with other Arcobacter reference species sequences available in the GenBank database, a total of ten sets of VAT gene-specific oligonucleotide primer pairs for A. faecis, ranging from 20 to 28 -mers, were designed. The ten pairs of primers, with their predicted fragment sizes, were used in one monoplex and four mPCR protocols as listed in Table 2. In order to check the specificity of the designed primers, initially, monoplex PCR assays were performed using only the forward and the reverse primer for detection of individual target gene. The PCR amplification reaction for each individual assay was carried out in the Mastercycler Gradient PCR system (Eppendorf, Hauppauge, NY), with a $25 \mu \mathrm{L}$ reaction mixture containing 10-50 ng of $A$. faecis LMG 28519 DNA template, $1 \mathrm{U}$ of $E x$-Taq DNA polymerase and the compatible PCR reagents, including $1 \times$ buffer with $\mathrm{MgCl}_{2}, 200 \mu \mathrm{M}$ each of the dNTPs (Fisher Scientific, Nepean, ON), $0.1 \mu \mathrm{M}$ of each set of the forward and reverse primer pair by adjusting volume to $25 \mu \mathrm{l}$ with sterile distilled water in each monoplex PCR assay.
The PCR reactions were conducted with an initial template denaturation $\left(94^{\circ} \mathrm{C}\right.$ for $\left.3 \mathrm{~min}\right)$ followed by $35 \mathrm{cy}-$ cles of amplification (denaturation at $94^{\circ} \mathrm{C}$ for $30 \mathrm{~s}$, annealing ranging from 54 to $59^{\circ} \mathrm{C}$ for $30 \mathrm{~s}$ and extension at $72^{\circ} \mathrm{C}$ for $30 \mathrm{~s}$ ) ending with a 5 min extension at $72^{\circ} \mathrm{C}$ for individual target genes. For all PCR reactions, A. faecis LMG 28519 as positive and A. butzleri ATCC 49616, A. cibarius LMG 21996 and A. lanthieri LMG 28516 reference strains as negative controls were used. The specificity of all ten primer sets was further evaluated individually using 13 Arcobacter spp. and 25 other bacterial reference species and strains (Table 1).

In order to detect VAT genes in a more rapid and robust manner, four mPCR assays were optimized by combining and standardizing PCR protocols using two or three VAT gene-specific oligonucleotide primers. Each assay was designed such that the combination of the two or three primer pairs distinctively differed by a minimum of $50 \mathrm{bp}$ in size in order to distinctively resolve PCR fragments on an agarose gel electrophoresis (Table 2). Based on the monoplex PCR

Table 2 List of oligonucleotide primer pairs and PCR protocols designed and optimized for the detection of VAT genes in A. faecis

\begin{tabular}{|c|c|c|c|c|}
\hline $\begin{array}{l}\text { Target VAT } \\
\text { Gene }\end{array}$ & Oligonucleotide Primer Sequences $\left(5^{\prime}-3^{\prime}\right)$ & Amplicon Size (bp) & Primer Concentration $(\mu \mathrm{M})$ & Annealing Temperature $\left({ }^{\circ} \mathrm{C}\right)$ \\
\hline \multicolumn{5}{|l|}{ Assay 1} \\
\hline \multirow[t]{2}{*}{ mviN } & mviN F: TTC TाT GCA GCA ACA TTG GG & 180 & 0.4 & 57 \\
\hline & mviN R: TGC TAC CAT AGG AAA TAG GGC & & 0.4 & \\
\hline \multirow[t]{2}{*}{$\operatorname{irg} A$} & $\operatorname{irgA}$ F: CTG GAC AGT ATG AAG GAA ACC C & 105 & 0.4 & \\
\hline & irgA R: TTG CTT GAG TCC ATA ACA ACC A & & 0.4 & \\
\hline \multicolumn{5}{|l|}{ Assay 2} \\
\hline \multirow[t]{2}{*}{$\mathrm{cadF}$} & cadF F: ATG GTG CAT TCG GAA ACT ACG G & 192 & 0.1 & 60 \\
\hline & cadF R: TTG GAG CTG GAG CAG GAA CTA & & 0.1 & \\
\hline \multirow[t]{2}{*}{ ty/A } & tylA F: TAG AAA CAA AGC AAG TGA ACT C & 116 & 0.2 & \\
\hline & tylA R: CCT CTT CAA GTA GCT CTA TAT T & & 0.2 & \\
\hline \multicolumn{5}{|l|}{ Assay 3} \\
\hline \multirow[t]{2}{*}{$c d t \mathrm{~A}$} & cdtA F: TGT AGC CGA TGA ACT TAG TGA AGT AGA G & 274 & 0.4 & 59 \\
\hline & cdtA R: CCC AAC TGT TGC TTG TCC CAT TA & & 0.4 & \\
\hline \multirow[t]{2}{*}{$\mathrm{CiaB}$} & ciaB F: AAG CAG TTG CCC TAG AGT GG & 196 & 0.4 & \\
\hline & ciaB R: AGT GCT GGT CGT CCA ACA TAA & & 0.4 & \\
\hline \multirow[t]{2}{*}{ pldA } & pldA F: GTG CTG CTG AAT TTA ACT GG & 145 & 0.4 & \\
\hline & pldA R: GCA ACA CCT ATT CCT ACA TाT G & & 0.4 & \\
\hline \multicolumn{5}{|l|}{ Assay 4} \\
\hline \multirow[t]{2}{*}{$c d t C$} & cdtC F: AAG CAG AGG GTG AAA TAG CC & 210 & 0.8 & 56 \\
\hline & cdtC R: GAT TAG CAA ACT GTC CAC CAA ATA C & & 0.8 & \\
\hline \multirow[t]{2}{*}{$\operatorname{tet}(\mathrm{W})$} & tet(W) F: ACA TCA TTG ATA CTC CAG GTC ACG & 120 & 0.2 & \\
\hline & tet(W) R: TाT CAC TाT GTG GTT GAA CCC CTC & & 0.2 & \\
\hline \multicolumn{5}{|l|}{ Assay 5} \\
\hline \multirow[t]{2}{*}{$\operatorname{tet}(\mathrm{O})$} & tetO F: GGA GGG GTT CAA CCA C AA AG & 88 & 0.1 & 54 \\
\hline & tetO R: CTA TGT AAA TAA AAT GGA TAG & & 0.1 & \\
\hline
\end{tabular}


results, $\mathrm{mPCR}$ assays were further optimized where various parameters particularly concentrations of primers (0.1 to 1.0 $\mu \mathrm{M}), E x$-Taq DNA polymerase (0.6 to $2 \mathrm{U}$ ), dNTPs (100 to $200 \mu \mathrm{M}$ each of the four dNTPs), buffer strength (1.0x to $2.0 \times)$ and concentration $(0.1-0.5 \mu \mathrm{M})$ were tested. The simultaneous gene amplifications were performed in a reaction volume of $25 \mu \mathrm{l}$ consisting of variable ( 1 to $100 \mathrm{ng} \mu \mathrm{L}^{-1}$ ) DNA concentrations. Four PCR tubes containing two or three sets of primer pairs for the simultaneous detection of nine target VAT genes were processed with an initial denaturation at $94^{\circ} \mathrm{C}$ for $2 \mathrm{~min}$ followed by 35 cycles (except 30 cycles for $c a d \mathrm{~F}$ and $t y l \mathrm{~A}$ genes) of amplification including denaturation at $94^{\circ} \mathrm{C}$ for $30 \mathrm{~s}$, different annealing temperatures (ranging from 54 to $60^{\circ} \mathrm{C}$ ) for each mPCR assay (Table 2) and extension at $72^{\circ} \mathrm{C}$ for $30 \mathrm{~s}$ ended with a 5 min final extension at $72^{\circ} \mathrm{C}$.

The expected amplicon sizes were small; therefore, each mono- and multiplex PCR reaction was electrophoresed on a $2.5 \%$ agarose gel matrix (Fisher Scientific). A 100 bp DNA size marker (Life Technologies, Grand Island, $\mathrm{NY}$ ) was used to confirm the expected amplicon sizes of each target gene. The agarose gels were stained (ethidium bromide $0.5 \mu \mathrm{g} \mathrm{mL}^{-1}$ ), scanned and photographed using an Alpha Imager (Fisher Scientific) gel documentation system.

\section{Gene-specific primers design and optimization of mono- and multiplex PCR assays for $A$. lanthieri}

For A. lanthieri, a total of 11 including six virulence $(\operatorname{cad} \mathrm{F}, \operatorname{cia\mathrm {B}}, \operatorname{irg} \mathrm{A}, m v i \mathrm{~N}, p l d \mathrm{~A}$, and $\operatorname{ty} l \mathrm{~A})$, two antibiotic resistance $[\operatorname{tet}(\mathrm{O})$ and $\operatorname{tet}(\mathrm{W})]$ and three cytolethal distending toxin $(c d t \mathrm{~A}, c d t \mathrm{~B}$, and $c d t \mathrm{C})$ genes were identified based on genome sequence analysis of $A$. lanthieri LMG 28516 reference strain. Each gene sequence was further aligned with the sequences of other Arcobacter reference species available in the GenBank database. For mono- and multiplex PCR assays, 11 A. lanthieri genespecific oligonucleotide primer sets (ranging from 20 to 24-mers) were designed from variable regions of each gene with a minimum of $50 \mathrm{bp}$ for easy differentiation of amplicons on an agarose gel electrophoresis analysis (Table 3 ). The specificity of each assay was individually performed as monoplex PCR using A. lanthieri LMG 28516 reference strain, several Arcobacter spp. and other bacterial species and strains as positive and negative controls, respectively.

Based on gene-specific amplification results of each developed monoplex PCR assay, four MPCR assays were further optimized using a combination of two or three sets of primer pairs of six virulence and three toxin genes. As mentioned in the preceding section, several parameters were investigated to optimize $\mathrm{MPCR}$ protocols including primer concentrations $(0.1$ to $1.0 \mu \mathrm{M})$, $E x$-Taq DNA polymerase (0.5 to $2 \mathrm{U})$, dNTPs (100 to
$200 \mu \mathrm{M}$ each of the four dNTPs) and buffer strength $(1.0 \times$ to $2.0 \times)$ along with Bovine Serum Albumin (BSA) concentration $(0.1$ to $0.3 \mu \mathrm{M})$ were tested in order to obtain equal intensity of the amplified $\mathrm{MPCR}$ products. The $\mathrm{mPCR}$ assays were performed in $25 \mu \mathrm{L}$ reactions with a minimum DNA concentration of $10 \mathrm{ng} \mu \mathrm{L}^{-1}$. Each mPCR assay, which incorporates the detection of either two or three virulence and/or toxin genes, consisted of a 35-cycle PCR program with an initial denaturation cycle of $94^{\circ} \mathrm{C}$ for $2 \mathrm{~min}$, intermediate intra-cycle steps of $30 \mathrm{~s}$ each for denaturation at $94^{\circ} \mathrm{C}$ along with annealing where temperatures (ranging from 55 to $62^{\circ} \mathrm{C}$ ) varied from assay to assay (Table 3 ) and extension at $72^{\circ} \mathrm{C}$ ended with a final elongation step of $5 \mathrm{~min}$ at $72^{\circ} \mathrm{C}$.

Each mono- and multiplex PCR product was analyzed on an agarose gel electrophoresis, visualized on an ultraviolet transilluminator and photographed as described above.

\section{Sensitivity and specificity assessment of mono- and multiplex PCR assays}

The sensitivity of eleven optimized mono- and multiplex PCR assays was evaluated with representation of each target VAT gene specific for $A$. faecis and $A$. lanthieri. The purified DNA of each target species reference strain was quantified spectrophotometrically at $260 \mathrm{~nm}$ optical density, and ten-fold serially diluted (ranging from $100 \mathrm{ng}^{\mathrm{L}} \mathrm{L}^{-1}$ to $10 \mathrm{pg}^{\mathrm{L}} \mathrm{L}^{-1}$ ) corresponding to $10^{5}$ to $10^{1} \mathrm{CFU} \mathrm{\textrm {mL } ^ { - 1 }}$ were prepared in sterile water. The detection limits were determined for each target species and gene by the mono- and multiplex PCR assays. In order to avoid any cross-reaction of our species- and gene-specific primers with Arcobacter species, other than A. faecis and A. lanthieri, and 40 other bacterial reference species and strains along with negative controls (PCR master mix without DNA template and water) were also included in each assay.

\section{Evaluation and validation of specificity of developed assays}

In order to evaluate the performance in terms of reproducibility and validity of the designed primers and PCR conditions for a total of three mono- and eight multiplex PCR assays, 29 A. faecis and ten A. lanthieri strains from various human and animal fecal sources and agricultural surface water samples were used for this study. The isolates were previously tested using standard conventional microbiology procedures and further confirmed by genus- and species-specific PCR assays as described above. Furthermore, the specificity of amplified products of 21 target VAT genes were evaluated by sequencing PCR amplicons of two of each target species isolated from fecal and water samples along with reference strains were purified using a QIAquick gel extraction kit 
Table 3 List of oligonucleotide primer pairs and protocols designed for the detection of VAT genes in A. lanthieri strains

\begin{tabular}{|c|c|c|c|c|}
\hline Target VAT Gene & Oligonucleotide Primer Sequences $\left(5^{\prime}-3^{\prime}\right)$ & Amplicon size (bp) & Primer Concentration $(\mu \mathrm{M})$ & Annealing Temperature $\left({ }^{\circ} \mathrm{C}\right)$ \\
\hline \multicolumn{5}{|l|}{ Assay 1} \\
\hline \multirow[t]{2}{*}{$c d t B$} & cdtB F: GCA AAA GGT GAT TGG GCT CC & 303 & 0.4 & 56 \\
\hline & cdtB R: TCC TCC AGC TCC TTG AAC AC & & 0.4 & \\
\hline \multirow[t]{2}{*}{ cadF } & cadF F: TCC AAC TCC AGT TGC TGC TC & 243 & 0.4 & \\
\hline & cadF R: TGT CCT TCG ATG TCA GCT TTC & & 0.4 & \\
\hline \multirow[t]{2}{*}{$\operatorname{irg} A$} & irgA F: AGA GCT GTT GGT TGG GAT GG & 186 & 0.4 & \\
\hline & irgA R: TGC ATT TGC TCT TGT AGG GT & & 0.4 & \\
\hline \multicolumn{5}{|l|}{ Assay 2} \\
\hline \multirow[t]{2}{*}{$c d t C$} & cdtC F: GAT GAA TCC ACC AGA AAT AGA G & 196 & 0.3 & 57 \\
\hline & $\operatorname{cdtC}$ R: TाT GGG ATC AAG AGT ATA AAG TTC & & 0.3 & \\
\hline \multirow[t]{2}{*}{ pldA } & pldA F: TGC TCC ATT TAG AGA AAC TAA C & 132 & 0.1 & \\
\hline & pldA R: GAA CGA GAT TCT TCA CCA TCT T & & 0.1 & \\
\hline \multicolumn{5}{|l|}{ Assay 3} \\
\hline \multirow[t]{2}{*}{$c d t A$} & cdtA F: CAG GAA TAG ATC TCG CTA CAA ATG & 220 & 0.3 & 55 \\
\hline & cdtA R: TाT GGT AGA AGA GGA AGT TCA TTG & & 0.3 & \\
\hline \multirow[t]{2}{*}{ mviN } & mviN F: ACC TIT GGT TCT TCA ACT TTA C & 170 & 0.4 & \\
\hline & mviN R: CGT GCT ACC ATA GGA AAT AGG & & 0.4 & \\
\hline \multicolumn{5}{|l|}{ Assay 4} \\
\hline \multirow[t]{2}{*}{$\mathrm{ciaB}$} & ciaB F: GAT AGA TGC TAT TCT GCT CTT G & 207 & 0.2 & 60 \\
\hline & ciaB R: ATC TTC ACT AAA TGC TAC TAT T & & 0.2 & \\
\hline \multirow[t]{2}{*}{ ty/A } & tylA F: GAC ATT GTA ACA TGT GAT GTA TCT T & 125 & 0.1 & \\
\hline & tylA R: TाT ACA TाT GTT CCC ACT TCA AA & & 0.1 & \\
\hline \multicolumn{5}{|l|}{ Assay 5} \\
\hline \multirow[t]{2}{*}{$\operatorname{tet}(\mathrm{O})$} & tetO F: TCA TAC ACT TAT ACA CTT GAT GC & 94 & 0.2 & 62 \\
\hline & tetO R: CTC TAT ATT CAT TTG CAA CAT CAA CT & & 0.2 & \\
\hline \multicolumn{5}{|l|}{ Assay 6} \\
\hline \multirow[t]{2}{*}{$\operatorname{tet}(\mathrm{W})$} & tetW F: AAT CAT ACA CTT ATA CAC TTG ATG CAC & 197 & 0.1 & 60 \\
\hline & tetW R: TTT AAT TCC TTC AAC TAT CTC TTC TTC & & 0.1 & \\
\hline
\end{tabular}

(Qiagen, USA). The purified PCR products were sequenced using an ABI 3130xL Genetic Analyzer (Applied Biosystems) according to the manufacturer's recommendations. The data was analyzed against the global database using a BLAST search engine for species- and gene-level confirmation of positive isolates.

\section{RNA extraction and $c d t$ gene expression analysis}

In order to examine the transcriptional expression of the $c d t(c d t \mathrm{~A}, c d t \mathrm{~B}$ and $c d t \mathrm{C})$ genes among $A$. faecis and $A$. lanthieri isolates, total RNA was extracted by using NucleoSpin RNA kit (Macherey Nagel, D-Mark Bioscience, Germany) according to the manufacturer's instructions. RNA was suspended in an appropriate amount of RNase-free water and RNA concentrations estimated by Qubit 3.0 fluorometer (Thermo Fisher Scientific, Waltham, MA, USA). Reverse transcriptase PCR (RT-PCR) was carried out using iScript gDNA
Clear cDNA synthesis kit (BioRad, USA) according to the manufacturer's instructions. RT-PCR primers listed in Tables 2 and 3 were used to amplify $c d t \mathrm{~A}, c d t \mathrm{~B}$ and $c d t C$ genes. PCR reactions were performed on the cDNA template after the addition of Taq DNA polymerase, deoxynucleoside triphosphates, $1 \times$ buffer with $\mathrm{MgCl}_{2}$ and each set of $c d t$ gene primers with the incubation conditions of $95^{\circ} \mathrm{C}$ for 2 min followed by $35 \mathrm{cy}$ cles at $95^{\circ} \mathrm{C}$ for $30 \mathrm{~s}, 56$ to $59^{\circ} \mathrm{C}$ for $30 \mathrm{~s}$ and $72^{\circ} \mathrm{C}$ for $30 \mathrm{~s}$ with a final incubation at $72^{\circ} \mathrm{C}$ for $5 \mathrm{~min}$. PCR products were run on a $2 \%$ agarose gel and visualized.

\section{Results}

Specificity and optimization of species- and gene-specific primers and protocols in monoplex PCR assays

Initially, the specificity of 21 VAT gene primers and optimization of PCR protocols for A. faecis and $A$. lanthieri were tested with their corresponding reference 
DNA by monoplex PCR (Tables 2 and 3), and confirmed the expected amplicon sizes by agarose gel electrophoresis (data not shown). In this optimization step, all ten and 11 VAT genes investigated were detected in the $A$. faecis and $A$. lanthieri reference strains, respectively. The $A$. faecis primers specifically amplified with expected amplicon sizes for six virulence [cadF (192 bp), ciaB (196 bp), irgA (105 bp), mviN (180 bp), pldA (145 bp) and tylA (116 bp)], two $c d t$ [cdtA (274 bp) and $c d t C(210 \mathrm{bp})]$ and two antibiotic resistance [tet $(\mathrm{O})$ (88 bp) and tet(W) (120bp)] genes, respectively. Similarly, for A. lanthieri reference strain, specific PCR products were obtained with expected sizes for six virulence [cadF (243 bp), ciaB (207 bp), irgA (186 bp), $m v i \mathrm{~N}$ (170 bp), pldA (132 bp) and tylA (125 bp)], three cytolethal distending toxin [ $c d t \mathrm{~A}(220 \mathrm{bp}), c d t \mathrm{~B}$ (303), and $c d t \mathrm{C}(196 \mathrm{bp})]$ and two antibiotic resistance [tet $(\mathrm{O})$ and tet(W)] genes with typical amplicon sizes of 94 and $197 \mathrm{bp}$, respectively. The specificity of the developed primers and monoplex PCR protocols for each target species and VAT genes was also tested on 15 Arcobacter and other bacterial reference strain DNA templates (Table 1 ). The results showed that all assays had specificities only for A. faecis and A. lanthieri reference strains tested.

\section{Development and optimization of $\mathrm{mPCR}$ assays}

Furthermore, a total of eight single-tube mPCR assays were developed and optimized for the detection of nine VAT genes in A. faecis and A. lanthieri reference strains, respectively. However, PCR assays for three antibiotic resitance genes including tet $(\mathrm{O})$ for $A$. faecis andtet $(\mathrm{O})$ and tet $(\mathrm{W})$ for $A$. lanthieri were remain used as monoplex due to the limitation in amplicon sizes and cross-amplification reaction with other genes investigated. To optimize the amplification of all primer pairs in the mPCR assays, initially the optimum annealing temperature for the $\mathrm{MPCR}$ reaction was determined. Temperature gradient PCR reactions determined that the appropriate annealing temperature ranged from 54 to $62^{\circ} \mathrm{C}$ for the mPCR assays. To further optimize each mPCR assay, the manipulation of primer concentration showed effective results. In each monoplex PCR assays, $0.4 \mu \mathrm{M}$ primer concentration was used; however; to improve differences in the levels and intensity of amplification between different amplicons, the concentration of the primer pairs that amplified more efficiently were optimized using 0.1 to $0.4 \mu \mathrm{M}$ concentration, while conversely, the concentration of the primer pair that amplified less efficiently were increased to $0.8 \mu \mathrm{M}$ (Tables 2 and 3). BSA significantly enhanced PCR amplification yield when used at $0.3 \mu \mathrm{M}$. In each case, the PCR assays showed no primer-dimer interference or nonspecific bands and produced the expected amplicon fragment sizes as obtained in monoplex PCR assays for
A. faecis including 180 and $105 \mathrm{bp}$ for $m v i \mathrm{~N}$ and $i r g \mathrm{~A}$ genes (Assay 1); 192 and $116 \mathrm{bp}$ for cadF and tylA genes (Assay 2); 274, 196 and $145 \mathrm{bp}$ for $c d t \mathrm{~A}, c i a \mathrm{~B}$ and pldA genes (Assay 3); 210 and $120 \mathrm{bp}$ for $c d t \mathrm{C}$ and tet $(\mathrm{W})$ genes (Assay 4$)$; whereas $88 \mathrm{bp}$ for tet $(\mathrm{O})$ gene (Assay 5) (Table 2; Fig. 1a, b, and c). On the other hand, each optimized mPCR assay, for A. lanthieri, produced same amplicons obtained during optimization of monoplex PCR assays with expected amplicon sizes of 303, 243 and $186 \mathrm{bp}$ for $c d t \mathrm{~B}, c a d \mathrm{~F}$ and $\operatorname{irg} \mathrm{A}$ genes (Assay 1); 196 and $132 \mathrm{bp}$ for $c d t \mathrm{C}$ and $p l d \mathrm{~A}$ genes (Assay 2); 220 and $170 \mathrm{bp}$ for $c d t \mathrm{~A}$ and $m v i \mathrm{~N}$ genes (Assay 3); 207 and $125 \mathrm{bp}$ for ciaB and tylA (Assay 4), whereas 94 bp for tet $(\mathrm{O})$ (Assay 5) and $197 \mathrm{bp}$ for tet $(\mathrm{W})$ (Assay 6)

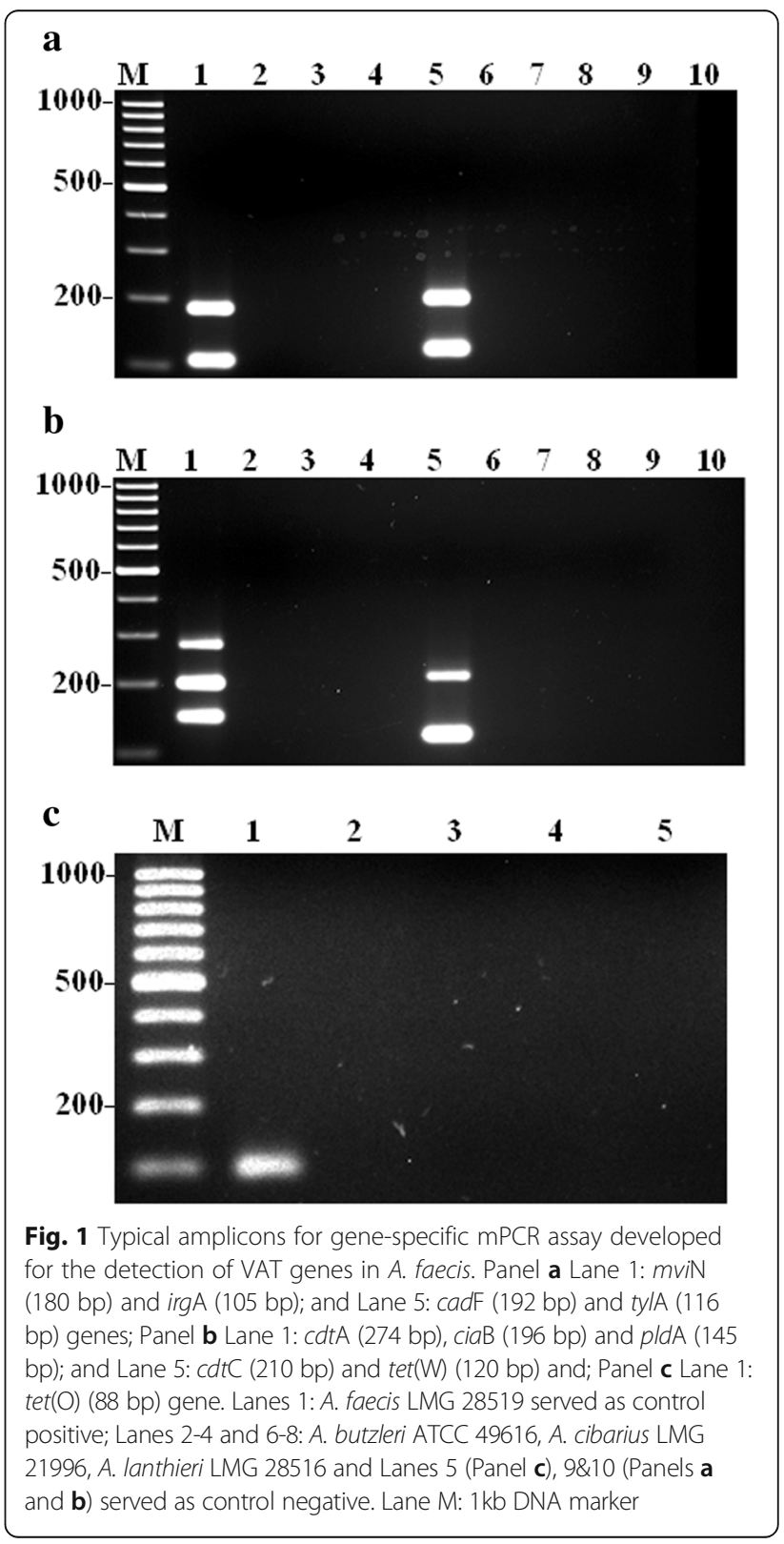


(Table 2; Fig. 2a, b and c). Each mPCR assay was further evaluated for the specificity of the protocol by using control reference strains of Arcobacter spp. The mono- and multiplex PCR products were specifically obtained for each target gene of reference or field strain DNA, which indicates an absence of interference and non-specificity between any of the VAT gene primers or among amplified products.

\section{Evaluation of developed PCR assays and prevalence of VAT genes}

In order to validate the developed mono- and multiplex PCR assays, and determine the degree of pathogenicity of the $A$. faecis and $A$. lanthieri by investigating the prevalence of VAT genes in field isolates, a total of 29

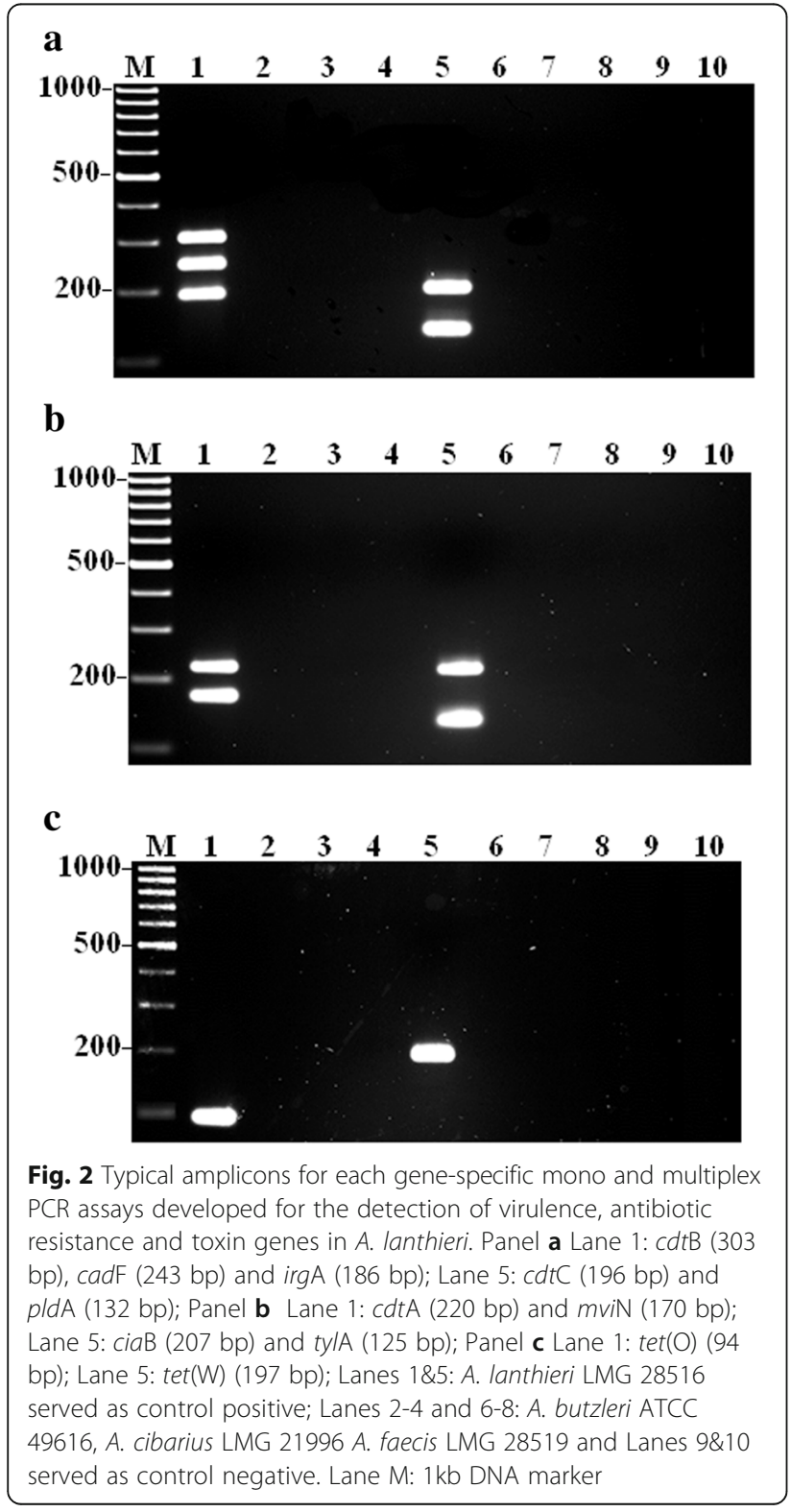

A. faecis cultures isolated from human and animal fecal and agricultural water samples were tested (Fig. 3). Interestingly, of the total ten VAT genes tested, all strains showed positive amplification for all genes at a high frequency ranging from 93 to $100 \%$ (Table 4) where $c a d \mathrm{~F}$, $\operatorname{irg} \mathrm{A}, t y l \mathrm{~A}, c d t \mathrm{C}$ and $t e t(\mathrm{~W})$ genes were detected in all strains. However, of the total ten A. lanthieri strains (Figs. 4 and 5), only one strain showed negative amplification reaction for all VAT genes. However, one strain showed negative amplification for $\operatorname{irg} \mathrm{A}, \operatorname{tyl} \mathrm{A}, \operatorname{tet}(\mathrm{O}), \operatorname{cdt} \mathrm{A}$ and $c d t$ C genes (Table 4). Similarly, based on the CLSI tetracycline breakpoints, all except one isolate of each species showed resistance to tetracycline which correlates with the $\operatorname{tet}(\mathrm{O})$ and tet $(\mathrm{W})$ gene and species-specific PCR results. In addition, of the total $29 \mathrm{~A}$. faecis and $10 \mathrm{~A}$. lanthieri isolates, results of the RT-PCR analyzing the expression of $c d t$ encoding gene showed detection of $c d t \mathrm{~A}(70 \% ; n=20)$ and $c d t \mathrm{C}(87 \%, n=25)$ genes in $A$. faecis compared to A. lanthieri isolates where expression of $c d t \mathrm{~A}, c d t \mathrm{~B}$ and $c d t \mathrm{C}$ genes was detected at a variable rate ranging from 60 to $70 \%$.

The specificity of each targeted gene-specific primer pair of A. faecis and A. lanthieri was confirmed by sequencing of positive amplicons of reference strains and selected field isolates (Additional file 1: Table S1). The sequences were confirmed by available sequence data analysis where $\geq 99 \%$ sequence homology was observed to the corresponding target species-specific VAT gene.

\section{Sensitivity of the developed PCR assays}

Furthermore, the detection sensitivity of each monoand multiplex PCR assay developed for a total of 21 genes of two target species was determined and confirmed by examining serially diluted (ten-fold) DNA

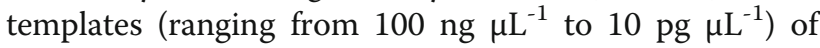
each target gene primer mixtures. Each targeted gene was amplified with a DNA concentration as low as $10 \mathrm{pg}$ $\mu \mathrm{L}^{-1}$ by observing distinctive multiple PCR products with expected amplicon sizes on a $2.5 \%$ agarose gel which suggests that a minimum of $10 \mathrm{pg} \mu \mathrm{L}^{-1}$ of genomic DNA can detect target VAT gene in one of the target species by using this method.

\section{Discussion}

Although Arcobacter spp. have been considered as emerging human pathogens, the pathogenicity, toxin production and virulence mechanism still need to be fully elucidated [32]. After the first A. butzleri genome sequence, several virulence-associated genes were revealed that showed similarities with other bacteria such as Campylobacter, E. coli and Vibrio spp. [19], while a number of studies reported the prevalence of these genes in Arcobacter spp. [6, 10, 14]. These study findings established a cornerstone in identifying Arcobacter as an 


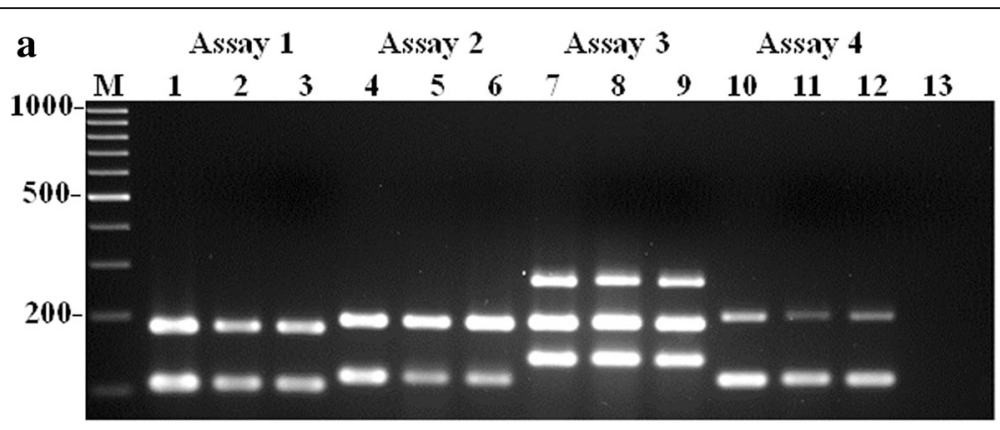

b

Assay 5

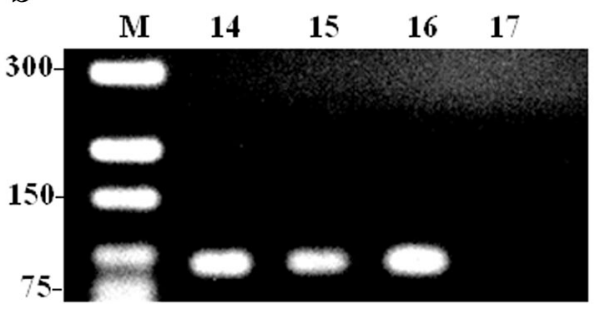

Fig. 3 Evaluation and validation of five species-specific mono- and multiplex PCR assays developed for the detection of VAT genes in A. faecis field isolates. Panels a and $\mathbf{b}$ Lanes 2-3: irgA and mviN genes; Lanes: 5-6 cadF and tylA genes; Lanes: 8-9 cdtA, ciaB and pldA; Lanes 11-12: cdtA and tet $(\mathrm{W})$ genes; and Lanes 15-16 tet( $\mathrm{O})$ gene. Lanes 1, 4, 7, 10 and 14: Control positive A. faecis LMG 28519; Lane 13\&17: Control negative; Lane M: $1 \mathrm{~kb}$ and 300 bp DNA Markers

important pathogen that has potential to cause health risk to humans and animals. Of the other available detection techniques, these studies applied PCR assay that has an ability to detect the pathogens and target genes more rapidly and accurately compared to culturing, microscopy, and antigen based tests that have limited detection capacity especially when it comes to detection of a specific gene or pathogenic organism to the species-level. However, mPCR assay can be performed from a single or set of DNA templates rather than analyzing several DNA aliquots for an individual species or gene where the results can be obtained in more efficient and cost effective manner by reducing the possibility of cross-contamination. The major advantage of combining multiple primer pairs together in a single-tube PCR assay reduces the overall quantity of materials used per assay, the amount of time required for high throughput screening, thereby reducing the cost of performing these assays in more robust and rapid manner. However, the major challenges in developing an MPCR assay are primer design, primer concentration, PCR protocol (e.g., annealing and extension time and cycles) and avoiding primer-dimer formation for obtaining an optimal amplification of multiple products for all target species or genes [46]. Formation of primer dimer occurs prior to the first PCR cycle and is typically caused by primers that have complementary overlaps. By choosing a variable terminal sequence at 3' ends of multiple primers, the formation of stable overlaps can successfully be avoided [47].

With the rapidly evolving technology, genome sequence analysis is becoming common to identify and confirm specific genes for assessing the pathogenicity of a microorganism because of the improved BLAST program and continuous update of genome data. This approach is more convenient and effective e.g., virulence and antibiotic resistance-specific genes were identified in A. butzleri and A. cryaerophilus by comparative genomics $[19,48]$. Researchers have developed MPCR assays for rapid identification of Arcobacter spp. [45, 49] as well as analysis of the virulence-associated genes of Arcobacter spp. [16]. The Arcobacter genus-specific virulence-

Table 4 Number (percent) of virulence, antibiotic resistance and toxin (VAT) genes detected in A. faecis and A. lanthieri strains isolated from agricultural surface water and various fecal sources

\begin{tabular}{|c|c|c|c|c|c|c|c|c|c|c|c|c|}
\hline \multirow[t]{2}{*}{ Species } & \multirow{2}{*}{$\begin{array}{l}\text { No. of } \\
\text { Isolates }\end{array}$} & \multicolumn{6}{|c|}{ Virulence genes } & \multicolumn{2}{|c|}{ Antibiotic resistance genes } & \multicolumn{3}{|c|}{ Toxin genes } \\
\hline & & cadF & ciaB & $\operatorname{irgA}$ & mviN & pldA & ty/A & $\operatorname{tet}(\mathrm{O})$ & tet $(\mathrm{W})$ & $c d t \mathrm{~A}$ & $c d t B$ & $c d t C$ \\
\hline A. faecis & 29 & $29(100)$ & $28(97)$ & $29(100)$ & $27(93)$ & $28(97)$ & $29(100)$ & $27(93)$ & $29(100)$ & $28(97)$ & $N D^{a}$ & $29(100)$ \\
\hline A. lanthieri & 10 & $9(90)$ & $9(90)$ & $8(80)$ & $9(90)$ & $9(90)$ & $8(80)$ & $8(80)$ & $9(90)$ & $8(80)$ & $9(90)$ & $8(80)$ \\
\hline
\end{tabular}

${ }^{\mathrm{a}}$ Gene not detected 


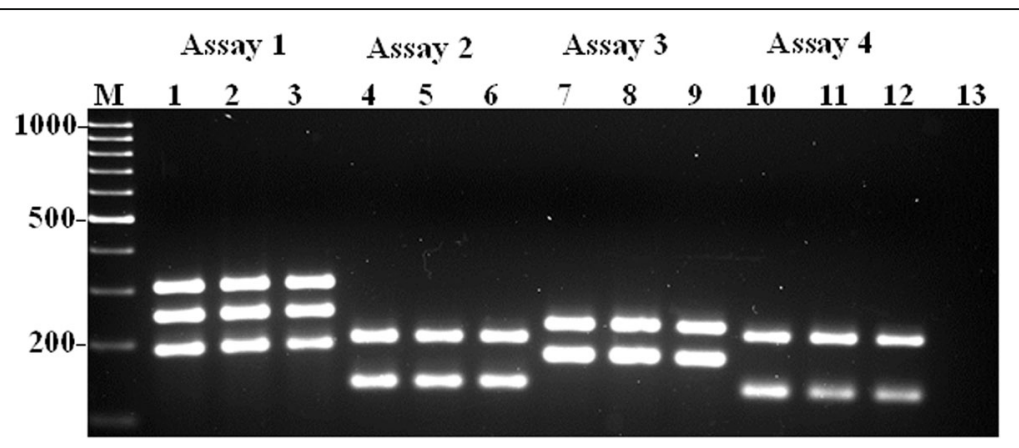

Fig. 4 Evaluation and validation of four species-specific mPCR assays developed for the detection of VAT genes in A. lanthieri field isolates (Lanes 2-3: $c d t B$, cadF, and irgA genes; Lanes 5-6: $c d t C$ and pldA genes; Lanes 8-9: cdtA and mviN genes; Lanes 11-12: ciaB and tylA genes). Lanes 1, 4, 7 and 10: A. lanthieri LMG 28516 control positive; Lane 13: Control negative; Lane M: 1kb DNA Marker

associated gene-based mono- and multiplex PCR assays have developed and are considered a better target for assessing the pathogenicity of Arcobacter spp. isolated from various sources $[10,11,16,50]$. However, these PCR assays were less accurate and failed to amplify all targeted virulence-associated genes in other Arcobacter spp. except $A$. butzleri likely due to heterogeneity in the primer sequences of other Arcobacter spp. [16]. Moreover, the $c d t(c d t \mathrm{~A}, c d t \mathrm{~B}$ and $c d t \mathrm{C})$ genes that play role as a virulence factor in promoting diseases by toxin-producing pathogens and genes that enable antibiotic resistance were not investigated in these studies [19, 51]. A. faecis and A. lanthieri are closely related to pathogenic species of Arcobacter (e.g., A. butzleri and A. cryaerophilus) $[4,13]$; however, there has been no species- and gene-specific screening method developed that can efficiently be used to determine the pathogenicity, antibiotic resistance and toxicity which are all important factors when assessing the level of health risk an organism causes to humans or animals.

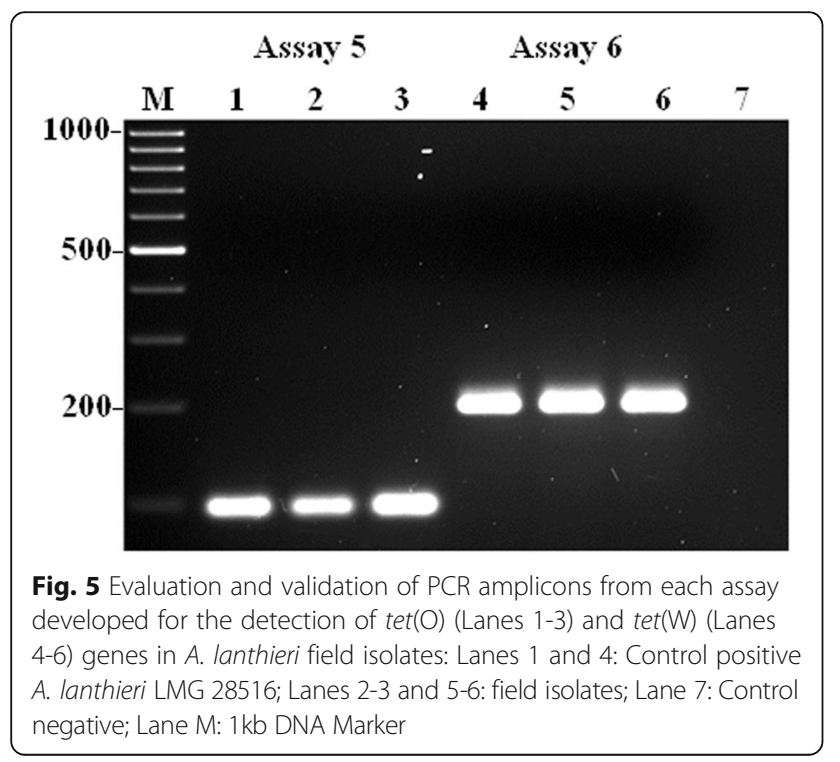

To our knowledge, this study reports the first Arcobacter species- and gene-specific mono- and multiplex PCR methods that have been developed and validated to detect and analyze the prevalence of several VAT genes in $A$. faecis and A. lanthieri individually. Although the initial time investment required to optimize species- or gene-specific mPCR assay was significantly more than that of the optimization of a monoplex assay, the longterm benefits are greater than the short-term costs. The high throughput and rapid screening of field isolates of both species for the analyses of the VAT genes cannot be understated. The process of optimizing species- and gene-specific mPCR assays commenced with careful design of primer pairs that may not only amplify sequences specific to the target gene, but also do not interfere with the other primer pairs used in each assay. Moreover, the fragment size can distinguishably be observed on an agarose gel. In the first phase of the study, all primers were carefully designed coupled with Ex-Taq DNA polymerase and BSA to improve yield and intensity of amplified products in a mixture of variable concentration of primers and DNA. To avoid preferential amplification of the shorter amplicons, we optimized multiple factors such as the concentration of each primer and the extension time of PCR cycles that may affect an mPCR assay. Although the primer pairs designed by considering various parameters using primer design software, they do not show optimized results until manipulation of several parameters (ranging from primers, Taq DNA polymerase, buffer and DNA concentrations to addition of BSA at various concentrations, annealing temperature and time in the PCR protocols) were applied during optimization of each mPCR assay. Moreover, multiple primer pairs with small amplicon sizes and distinctive differentiation preferably with a minimum amplicon length difference of $50 \mathrm{bp}$ between amplicons of multiple target genes were designed for an MPCR assay with the aim to apply these assays in a real-time PCR environment which made optimization of each 
single-tube mPCR assay more challenging. After optimization of the above mentioned parameters, specific and consistent amplification of all targeted VAT genes in the mono- and multiplex PCR combinations were successfully achieved where a total of 11 including three mono- and eight multiplex PCR-based assays were developed, optimized and validated for the identification and differentiation of six virulence $(\operatorname{irg} \mathrm{A}, m v i \mathrm{~N}, \operatorname{cad} \mathrm{F}, t y l \mathrm{~A}$, $c i a \mathrm{~B}$ and $p l d \mathrm{~A})$, two antibiotic resistance $[\operatorname{tet}(\mathrm{O})$ and $t e t(\mathrm{~W})]$ and two/ three cytolethal distending toxin $(c d t \mathrm{~A}$, $c d t \mathrm{~B}$ and $c d t \mathrm{C}$ ) genes in A. faecis and A. lanthieri, respectively. In the first step, the primer set for each gene was individually optimized and tested in $A$. faecis and $A$. lanthieri reference strains where positive amplification reactions of all targeted VAT genes with expected product sizes were observed. Based on the monoplex PCR assay results, eight mPCR assays were further developed using a combination of two or three VAT gene primer pairs. Each optimized MPCR assay gave results consistent and similar, in terms of size and intensity, to the monoplex PCR assay and effectively detected VAT genes by distinguishably producing 18 clear bands in eight mPCR assays on an agarose gel electrophoresis. Due to limitations in fragment size and cross-reaction with primer pairs of other VAT genes, tet $(\mathrm{O})$ and tet(W) gene were used as monoplex PCR assays.

To demonstrate the future utility and asses the degree of pathogenicity, the developed mono- and multiplex PCR assays were further validated by testing $A$. faecis and $A$. lanthieri strains isolated from agricultural surface water and fecal samples. Of the total ten VAT genes, $\operatorname{cad} \mathrm{F}, \operatorname{irg} \mathrm{A}, \operatorname{tyl} \mathrm{A}, \operatorname{tet}(\mathrm{W})$ and $c d t \mathrm{C}$ genes were detected in all $A$. faecis field isolates compared to one isolate that did not show amplification to $c i a \mathrm{~B}, p l d \mathrm{~A}$, and $c d t \mathrm{~A}$ genes; whereas, two isolates were negative for $m v i \mathrm{~N}$ and $\operatorname{tet}(\mathrm{O})$ genes. On the other hand, one strain of A. lanthieri showed negative amplification for all 11 VAT genes compared to two strains that did not amplify $\operatorname{irgA}, t y l \mathrm{~A}, t e t(\mathrm{O}), c d t \mathrm{~A}$ and $c d t \mathrm{C}$ genes when field isolates were tested for evaluation and validation of developed assays. The results are in agreement with other studies where $c a d \mathrm{~F}, c i a \mathrm{~B}, m v i \mathrm{~N}, p l d \mathrm{~A}$, and $t y l \mathrm{~A}$ virulence genes were detected at a high frequency in $A$. butzleri and $A$. skirrowii strains suggesting that these genes are common within the genus Arcobacter [10, 11, 14-16, 32, 52]. A high prevalence of ciaB gene suggests that $A$. faecis and $A$. lanthieri are able to easily internalize into epithelial cells in the gastrointestinal lining that contributes in mediating enteritis [18]. On the other hand, $\operatorname{irgA}$ gene was detected in A. faecis and $A$. lanthieri strains tested which is not in concordance with previous studies where $\operatorname{irgA}$ gene was detected at a low frequency in Arcobacter spp. [10, 11]. The key function of irgA in vivo is uptake of iron, which is an essential but often severely limited nutrient in animal hosts meaning that low iron concentrations are less likely to prevent the pathogen from infecting and colonizing the host. This gene plays a key role in causing urinary tract infection by uropathogenic $E$. coli $[53,54]$. However, the prevalence of $\operatorname{irgA}$ was significantly higher than the frequency observed in the aforementioned studies. This could be due to geographical differences from where the sample was obtained, for instance the samples analyzed in this study were isolated in Canada while these studies contained strains isolated from other parts of the world. Interestingly, similar to A. faecis, tet $(\mathrm{O})$ and tet $(\mathrm{W})$ antibiotic resistance genes were also detected at a significantly high frequency in $A$. lanthieri. The results are also supported by the previous study $[31,48]$ where tetracycline resistance in A. cryaerophilus was observed, suggesting that tetracycline resistance is more frequent in the genus Arcobacter than reported. Other than Arcobacter and Campylobacter spp., $\operatorname{tet}(\mathrm{O})$ and $\operatorname{tet}(\mathrm{W})$ genes were detected more significantly than other tet-genes [e.g., tet $(\mathrm{B})$ and tet $(\mathrm{C})]$ in commensal bacteria isolated from fecal and water samples [55]. Interestingly, similar to our optimized PCR assays where $\geq 93$ A. faecis and $\geq 80 \%$ A. lanthieri isolates showed positive amplification for tet $(\mathrm{O})$ and tet $(\mathrm{W})$ genes, the phenotypic resistance to tetracycline was also observed at a significantly high (97\%) rate in both species. These results suggest that when these species are clinically identified for tetracycline resistance, genotypic screening should be performed for the presence of tet genes since rapid, simple and reliable methods for antibiotic susceptibility are important for appropriate therapy. Moreover, identification and determination of the antimicrobial susceptibility test that requires a minimum of 3-days compared to the developed PCR assays that can be done in a few hours, therefore, the developed PCR assays can be used for confirmation of the results obtained by conventional phenotypic methods when necessarily required.

In contrary to the previous studies [19, 22], which reported the distinct absence of $c d t$ genes in arcobacters and in whole genome sequence of $A$. butzleri, $c d t \mathrm{~A}$ and $c d t \mathrm{C}$ genes were identified in $A$. faecis genome sequence where PCR assays detected these genes at high frequency (cdt A 93\% and $c d t \mathrm{C} 100 \%$ ) in field isolates. Interestingly, $c d t \mathrm{~B}$ gene was not identified in the genome sequence of the $A$. faecis reference strain. This leads to a future research on genome sequencing of one of the field isolates that might contain all three $c d t$ genes. If that is not the case, given bacterial ability to rapidly acquire new genes, it remains important to note that the field isolates currently possess both $c d t$ genes that were investigated in this study. In contrast to $A$. faecis, all three $c d t(c d t \mathrm{~A}, c d t \mathrm{~B}, c d t \mathrm{C})$ genes were found in the $A$. lanthieri genome sequence. The rates of detection of $c d t \mathrm{~A}, c d t \mathrm{~B}$ and $c d t \mathrm{C}$ were 
significantly high where eight strains (80\%) were shown positive for $c d t \mathrm{~A}$ and $c d t \mathrm{C}$ genes compared to $c d t \mathrm{~B}$ gene detected in nine strains (90\%). The $c d t$ genes were also detected at a variable frequency in Campylobacter spp. isolated from various sources [56-58]. The high frequency of prevalence of VAT genes and the results of the expression analysis of $c d t$ genes where genes are functional in A. faecis and $A$. lanthieri strains indicate that these species of Arcobacter could potentially be pathogenic that can pose health risks to humans and animals.

One of the major advantages of these newly developed PCR assays is the significant specificity and sensitivity where each mono- or multiplex PCR assay showed specificity to their target species-specific genes at a least detection limit of $10 \mathrm{pg} \mu \mathrm{L}^{-1} \mathrm{DNA}$

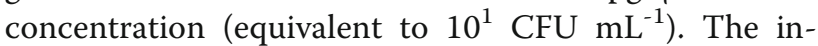
fectious dose for each pathogen varies; however, according to US EPA [59] guidelines, a pathogen can cause a disease when ingested at the rate of $\geq 10^{3}$ $\mathrm{CFU} \mathrm{mL}^{-1}$. Although the infectious dose of A. faecis and $A$. lanthieri is not determined yet, the detection sensitivity of each assay is within the range that has been used for other bacterial pathogens and can be applied for developing standard for infectious dose and pathogenicity assessment of these species isolated from clinical and various environmental niches.

\section{Conclusion}

The significance of investigating and detecting several VAT genes in A. faecis and A. lanthieri reference and field strains by developing, optimizing and validating eleven mono- and multiplex PCR assays described in this study would add useful knowledge to apply in the field of molecular microbiology. Moreover, the sensitivity, reproducibility and speed of the eight MPCR assays are enhanced due to the optimal application of several PCR parameters and addition of BSA that further enhanced the specificity of the assays by testing several other Arcobacter and bacterial species and strains as control. Overall, the rapidness and number of VAT genes tested in the developed PCR assays suggest that these novel PCR-based cost effective methods can be applied for rapid and possibly high throughput screening and assessment of pathogenic $A$. faecis and $A$. lanthieri strains in diagnostic laboratories and etiological/ epidemiological studies. Based on these results, further research is warranted to assess the role of these virulence factors on human or animal health by gene expression analysis or analysing the adhesive, invasive and toxicity capabilities in cell cultures using clinical and environmental isolates under various environmental conditions.

\section{Additional file}

Additional file 1: Table S1. Validation of VAT PCR assays by sequencing of PCR products for $A$. faecis and $A$. lanthieri reference and field strains isolated from fecal and water samples. (DOCX $27 \mathrm{~kb}$ )

\section{Abbreviations \\ ASIA: Arcobacter Selective Isolation Agar; BSA: Bovine Serum Albumin; cdt: Cytolethal distending toxin; mPCR: Multiplex PCR; tet: Tetracycline resistance; VAGs: Virulence-associated genes; VAT: Virulence, antibiotic resistance and toxin}

\section{Acknowledgements}

We thank co-op students Linda Liu, Mary G. Miltenburg, Mark Libby, and other field crew for collecting samples and providing laboratory and technical assistance.

\section{Funding}

The funds for this research were provided by Agriculture and Agri-Food Canada under project J-001012. The funding source was not involved in study design, sample collection, data analysis and interpretation.

\section{Availability of data and materials}

The data generated and analyzed in this study are available upon request. In this paper, all additional data generated or analyzed in this research study is presented as Additional file 1: Table S1.

\section{Authors' contributions}

$M Z, Z A$, and IK conceived study, performed genome sequence analyses and designed the experiments. MZ, MC and IK designed primers and PCR protocols, performed laboratory experiments, analyzed results and drafted the manuscript. ET, GT, GW, MS and DL coordinated in selecting field sampling sites and sample collection protocols as well as contributed in interpreting results data and editing manuscript. All authors reviewed, edited and approved the final manuscript.

Ethics approval and consent to participate Not applicable.

\section{Consent for publication}

Not applicable.

\section{Competing interests}

The authors declare that they have no competing interest.

\section{Publisher's Note}

Springer Nature remains neutral with regard to jurisdictional claims in published maps and institutional affiliations.

\section{Author details \\ 'Ottawa Research and Development Centre (ORDC), Agriculture and Agri-Food Canada, 960 Carling Ave., Ottawa, Ontario K1A 0C6, Canada. ²Department of Biology, McMaster University, Hamilton, Ontario L8S 4L8, Canada. ${ }^{3}$ School of Information Technology and Engineering, University of Ottawa, Ottawa, Ontario K1N 6N5, Canada. ${ }^{4}$ London Research and Development Centre (LRDC), Agriculture and Agri-Food Canada, London, Ontario N5V 4T3, Canada. ${ }^{5}$ Sherbrooke Research and Development Centre (SRDC), Agriculture and Agri-Food Canada, Sherbrooke, Quebec J1M 0C8, Canada.}

Received: 25 May 2018 Accepted: 28 November 2018 Published online: 11 January 2019

\footnotetext{
References

1. Vandamme P, Falsen E, Rossau R, Hoste B, Segers P, Tytgat R, De Ley J. Revision of Campylobacter, Helicobacter, and Wolinella taxonomy: emendation of generic descriptions and proposal of Arcobacter gen. nov. Int J Syst Bacteriol. 1991;41(1):88-103.
} 
2. Diéguez AL, Balboa S, Magnesen T, Romalde JL. Arcobacter lekithochrous sp. nov., isolated from a molluscan hatchery. Int J Syst Evol Microbiol. 2017;67: $1327-32$.

3. Vandamme P, Vancanneyt M, Pot B, Mels L, Hoste B, Dewettink D, Vlaes L, van den Borre C, Higgins R, Hommez J. Polyphasic taxonomic study of the emended genus Arcobacter with Arcobacter butzleri comb. nov., and Arcobacter skirrowii sp. nov., an aerotolerant bacterium isolated from veterinary specimens. Int J Syst Evol Bacteriol. 1992;42:344-56.

4. Whiteduck-Léveillée K, Whiteduck-Léveillée J, Cloutier M, Tambong JT, Xu R, Topp E, Arts MT, Chao J, Adam Z, Lévesque CA, Lapen DR, Villemur R, Talbot G, Khan IU. Identification, characterization and description of Arcobacter faecis sp. nov., isolated from human waste septic tank. Syst App Microbiol. 2016;39:93-9.

5. Levican A, Alkeskas A, Günter C, Forsyth SJ, Figueras MJ. The adherence and invasion of human intestinal cells by Arcobacter species and their virulence genotype. Appl Environ Microbiol. 2013;79(16):4951-7.

6. Levican A, Collado L, Figeuras MJ, Aguilar C, Yustes C, Diéguez AL, Romalde JL. Arcobacter bivalviorum sp. nov. and Arcobacter venerupis sp. nov. new species isolated from shellfish. Syst Appl Microbiol. 2012;35(3):133-8.

7. Ho HT, Lipman LJ, Gaastra W. Arcobacter, what is known and unknown about a potential foodborne zoonotic agent! Vet Microbiol. 2006;115:1-13.

8. D'Sa EM, Harrison MA. Effect of $\mathrm{pH}, \mathrm{NaCl}$ content, and temperature on growth and survival of Arcobacter spp. J Food Prot. 2005;68:18-25.

9. Bessede E, Delcamp A, Sifre E, Buissonniere A, Megraud F. New methods for detection of campylobacters in stool samples in comparison to culture. J Clin Microbiol. 2011;49:941-4.

10. Douidah $L$, de Zutter L, Baré J, De Vos P, Vandamme P, Vandenberg O, Van den Abeele M, Houf K. Occurrence of putative virulence genes in Arcobacter species isolated from humans and animals. J Clin Microbiol. 2012;50(3):73541.

11. Karadas G, Sharbati S, Hänel I, Messelhäußer U, Glocker E, Alter T, Gölz G. Presence of virulence genes, adhesion and invasion of Arcobacter butzleri. Appl Microbiol. 2013;115(2):583-90.

12. Tan J, File T, Salata R, Tan M. Infectious diseases. Expert guide series. In: The American College of Physicians. Philadelphia: Versa Press; 2008. p. 95.

13. Whiteduck-Léveillée $K$, Whiteduck-Léveillée J, Cloutier M, Tambong JT, Xu R, Topp E, Arts MT, Chao J, Adam Z, Lévesque CA, Lapen DR, Villemur R, Talbot G, Khan IU. Arcobacter lanthieri sp. nov., isolated from pig and dairy cattle manure. Int J Syst Evol Microbiol. 2015;65:2709-16.

14. Tabatabaei M, Shirzad AH, Shavegh $H$, Khoshbakht R. Occurrence of six virulence-associated genes in Arcobacter species isolated from various sources in Shiraz, Southern Iran. Microb Pathol. 2014;66:1-4.

15. Girbau C, Guerra C, Martinez-Malaxetxebarria I, Alonso R, Fernandez-Astorga A. Prevalence of ten putative virulence genes in the emerging foodborne pathogen Arcobacter isolated from food products. Food Microbiol. 2015;52: 146-9.

16. Whiteduck-Léveillée J, Cloutier M, Topp E, Lapen DR, Talbot G, Villemur R, Khan IU. Development and evaluation of multiplex PCR assays for rapid detection of virulence-associated genes in Arcobacter species. J Microbiol Methods. 2016;121:59-65.

17. Konkel ME, Garvis SG, Tipton SL, Anderson DE Jr, Cieplak W Jr. Identification and molecular cloning of a gene encoding a fibronectin-binding protein (CadF) from Campylobacter jejuni. Mol Microbiol. 1997;24:953-63.

18. Konkel ME, Kim BJ, Rivera-Amill V, Garvis SG. Bacterial secreted proteins are required for the internalization of Campylobacter jejuni into cultured mammalian cells. Mol Microbiol. 1999;32(4):691-701.

19. Miller WG, Parker $C T$, Rubenfield $M$, Mendz GL, Wösten MMSM, Ussery DW, Stolz JF, Binnewies T, Hallin PF, Wang G, Malek JA, Rogosin A, Stanker LH, Mandrell RE. The complete genome sequence and analysis of the Epsilonproteobacterium Arcobacter butzleri. Plos One. 2007;2(12):e1358.

20. Cao L, Volgina A, Huang CM, Korostoff J, DiRienzo JM. Characterization of point mutations in the $c d t A$ gene of the cytolethal distending toxin of Actinobacillus actinomycetemcomitans. Mol Microbiol. 2005;58:1303-21.

21. Purdy D, Leach SA, Hodgson AE, Buswell CM, Henderson I, McAlpine K. Characterisation of cytolethal distending toxin (CDT) mutants of Campylobacter jejuni. J Med Microbiol. 2000;49:473-9.

22. Johnson LG, Murano EA. Lack of a cytolethal distending toxin among Arcobacter isolated from various sources. J Food Prot. 2002;65(11):1789-95.

23. Adam Z, Whiteduck-Léveillée $K$, Cloutier M, Chen W, Lewis CT, Lévesque CA, Topp E, Lapen DR, Tambong JT, Talbot G, Khan IUH. Draft genome sequences of two Arcobacter strains isolated from human feces. Genome Announc. 2014a;2(2):e00113-4.

24. Adam Z, Whiteduck-Léveillée $K$, Cloutier $M$, Chen W, Lewis $C T$, Lévesque CA, Topp E, Lapen DR, Tambong JT, Talbot G, Khan IUH. Draft genome sequences of three Arcobacter strains of pig and dairy cattle manure origin. Genome Announc. 2014b;2(3):e00377-14.

25. Granados-Chinchilla F, Rodríguez C. Tetracyclines in food and feedingstuffs: From regulation to analytical methods, bacterial resistance, and environmental and health implications. J Anal Methods Chem. 2017;2017:124.

26. Chattopadhyay MK. Use of antibiotics as feed additives: a burning question. Front Microbiol. 2014;5:334.

27. Hao H, Cheng G, lqbal Z, Xiaohui A, Hussain HI, Huang L, Dai M, Wang Y, Liu Z, Yuan Z. Benefits and risks of antimicrobial use in food-producing animals. Front Microbiol. 2014:5:1-11.

28. Quesada SP, Paschoal JAR, Reyes FAG. Considerations on the aquaculture development and on the use of veterinary drugs: special issue for fluoroquinolones - a review. J Food Sci. 2013;78:1321-33.

29. US FDA. 2017. \#209 Guidance for Industry, The Judicious Use of Medically Important Antimicrobial Drugs in Food-Producing Animals, http://www.fda. gov/downloads/AnimalVeterinary/GuidanceComplianceEnforcement/ Guidanceforlndustry/UCM216936.pdf.

30. Van Boeckel TP, Brower C, Gilbert M, Grenfella BT, Levina SA, Robinsoni TP, Teillant A, Laxminarayan R. Global trends in antimicrobial use in food animals. PNAS. 2015;112:5649-54.

31. Yesilmen $\mathrm{S}$, Vural $\mathrm{A}$, Erkan ME, Yildirim $\mathrm{IH}$. Prevalence and antimicrobial susceptibility of Arcobacter species in cow milk, water buffalo milk and fresh village cheese. Int J Food Microbiol. 2014;188:11-4.

32. Ferreira S, Queiroz JA, Oleastro M, Domingues FC. Insights in the pathogenesis and resistance of Arcobacter: A review. Crit Rev Microbiol. 2014; $25: 1-20$.

33. Otth L, Wilson M, Cancino R, Fernández $\mathrm{H}$. In vitro susceptibility of Arcobacter butzleri to six antimicrobial drugs. Arch Med Vet. 2004;36(2):20710.

34. Son I, Englen MD, Berrang ME, Fedorka-Cray PJ, Harrison MA. Antimicrobial resistance of Arcobacter and Campylobacter from broiler carcasses. Int J Antimicrob Agents. 2007;29:451-5.

35. Connell SR, Tracz DM, Neirhaus KH, Taylor DE. Ribosomal protection proteins and their mechanism of tetracycline resistance. Antimicrob Agent Chemo. 2003;47(12):3675-81.

36. Schnappinger D, Hillen W. Tetracyclines: antibiotic action, uptake, and resistance mechanisms. Arch Microbiol. 1996;165:359-69.

37. Roberts MC. Update on acquired tetracycline resistance genes. FEMS Microbiol Lett. 2005;45(2):195-203.

38. Levy SB, McMurry LM, Barbosa TM, Burdett V, Courvalin P, Hillen W, Roberts MC, Rood Jl, Taylor DE. Nomenclature for new tetracycline resistance determinants. Antimicrob Agents Chemother. 1999;43:1523-4.

39. Billington SJ, Songer JG, Jost B. Widespread distribution of a Tet W determinant among tetracycline-resistant isolates of the animal pathogen Arcanobacterium pyogenes. Antimicrob Agents Chemother. 2002;46:1281-7

40. Chopra I, Roberts M. Tetracycline antibiotics: mode of action, applications, molecular biology, and epidemiology of bacterial resistance. Microbiol Mol Biol Rev. 2001;65:232-60.

41. Harmon KM, Wesley IV. Identification of Arcobacter isolates by PCR. Lett Appl Microbiol. 1996;23:241-4.

42. Khan IUH, Cloutier M, Libby M, Lapen DR, Wilkes G, Topp E. Enhanced single-tube multiplex PCR assay for detection and identification of six Arcobacter species. J Appl Microbiol. 2017;123(6):1522-32. https://doi.org/10. 1111/jam.13597.

43. Clinical and Laboratory Standards Institute (CLSI). Methods for antimicrobial dilution and disk susceptibility testing of infrequently isolated fastidious bacteria; Approved Guideline-Second Edition. CLS document M45-A2. Wayne, PA: Clinical and Laboratory Standards Institute; 2010

44. Clinical and Laboratory Standards Institute (CLSI). Performance Standards for Antimicrobial Susceptibility Testing. 21st informational supplement. CLSI M100-S21. Wayne, PA: Clinical and Laboratory Standards Institute; 2011.

45. Khan IUH, Hill S, Nowak E, Edge TA. Effect of incubation temperature on the detection of thermophilic Campylobacter species from freshwater beaches, nearby wastewater effluents, and bird fecal droppings. Appl Environ Microbiol. 2013;79(24):7639-45. 
46. Henegariu $\mathrm{O}$, Heerema NA, Diouhy SR, Vance GH, Vogt PH. Multiplex PCR: critical parameters and step-by-step protocol. BioTech. 1997;23:504-11.

47. Dieffenbach CW, Lowe TM, Dveksler GS. General concepts for PCR primer design. Genome Res. 1993;3:530-7.

48. Millar JA, Raghavan R. Accumulation and expression of multiple antibiotic resistance genes in Arcobacter cryaerophilus that thrives in sewage. PeerJ. 2017;5:e3269.

49. Houf K, Tutenel A, De Zutter L, Van Hoof J, Vandamme P. Development of a multiplex PCR assay for the simultaneous detection and identification of Arcobacter butzleri, Arcobacter cryaerophilus and Arcobacter skirrowii. FEMS Microbiol Lett. 2000;193(1):89-94.

50. Rathlavath S, Kohli V, Singh AS, Lekshmi M, Tripathi G, Kumar S, Nayak BB. Virulence genotypes and antimicrobial susceptibility patterns of Arcobacter butzleri isolated from seafood and its environment. Int J Food Microbiol. 2017:263:32-7

51. Pickett $\mathrm{CL}$, Whitehouse CA. The cytolethal distending toxin family. Trends Microbiol. 1999;7(7):292-7.

52. Lehmann J, Leroux C, Reimbold G, Charles M, Torres A, Morvan E, Baines Y, Ghibaudo G, Bano E. Novel sheet resistance measurement on AlGaN/GaN HEMT wafer adapted from four-point probe technique. Proceedings of the 2015 International Conference on Microelectronic Test Structures; 2015. p. 163-8.

53. Bauer RJ, Zhang L, Foxman B, Siitonen A, Jantunen ME, Saxen H, Marrs CF. Molecular epidemiology of 3 putative virulence genes for Escherichia coli urinary tract infection-usp, iha, and iroN (E. coli). J Infect Dis. 2002;185:15214.

54. Tashima KT, Carrol PA, Rogers MB, Calderwood SB. Relative importance of three iron-regulated outer membrane proteins for in vivo growth of vibrio cholera. Infect Immun. 1996;64(5):1756-61.

55. Yang H, Byelashov OA, Geornaras I, Goodridge LD, Nightingale KK, Belk KE, Smith GC, Sofos JN. Presence of antibiotic-resistant commensal bacteria in samples from agricultural, city, and national park environments evaluated by standard culture and real-time PCR methods. Can J Microbiol. 2010;56: 761-70.

56. Krutkiewicz A, Klimuszko D. Genotyping and PCR detection of potential virulence genes in Campylobacter jejuni and Campylobacter coli isolates from different sources in Poland. Folia Microbiol. 2010:55(2):167-75.

57. Laprade N, Cloutier M, Lapen DR, Topp E, Wilkes G, Villemur R, Khan IUH Detection of virulence, antibiotic resistance and toxin (VAT) genes in Campylobacter species using newly developed multiplex PCR assays. J Microbiol Meth. 2016;124:41-7.

58. Zheng J, Meng J, Zhao S, Singh R, Song W. Adherence to and invasion of human intestinal epithelial cells by Campylobacter jejuni and Campylobacter coli isolates from retail meat products. J Food Prot. 2006;69:768-74.

59. US, EPA. Guidelines for water reuse United States Environmental Protection Agency, Washington DC. 1992.

Ready to submit your research? Choose BMC and benefit from:

- fast, convenient online submission

- thorough peer review by experienced researchers in your field

- rapid publication on acceptance

- support for research data, including large and complex data types

- gold Open Access which fosters wider collaboration and increased citations

- maximum visibility for your research: over $100 \mathrm{M}$ website views per year

At BMC, research is always in progress.

Learn more biomedcentral.com/submissions 